\title{
FAKTOR FAKTOR YANG MEMPENGARUHI PENGHIMPUNAN DEPOSITO BERJANGKA PADA BANK UMUM PEMERINTAH DAN BANK SWASTA NASIONAL DI INDONESIA
}

\author{
Hj. Irma Setiawaty*
}

\section{A. PENDAHULUAN}

Seperti negara berkembang lainnya. Indonesia mengalami kekurangan dana domestik guna membiayai pembangunan. Upaya mendatangkan modal asing untuk menutup kekurangan tabungan domistik, sangat diperlukan agar target pertumbuhan ekonomi yang cukup tinggi dapat dicapai.

Salah satu jenis modal yang masuk ke Indonesia adalah pinjaman luar negeri baik yang mengalir kesektor swasta, maupun sektor pemerintah. Pengunaan pinjaman luar negeri mempunyai pelengkap dana domestik yang masih belum memadai untuk membiayai seluruh proses pembangunan di Indonesia. Namun demikian penggunaan pinjaman luar negeri yang semakin besar porsinya dalam pembiayaan pembangunan, telah menciptakan ketergantungan terhadap negara-negara pendonor, yang menimbulkan beban yang semakin berat, dan turut andil pada terjadinya krisis nilai tukar dan krisis ekonomi Indonesia pada tahun 1997.

Untuk memperkokoh pondasi bagi proses pembangunan dan pertumbuhan ekonomi Indonesia, salah satu upaya yang dilakukan adalah mengurangi ketergantungan dari arus modal asing (terutama arus modal jangka pendek) dan pinjaman luar negeri yang telah menjadi salah satu penyebab ambruknya perekonomian Indonesia. Dengan kaitan dengan inilah maka usaha mobilisasi dan domestik merupakan masalah yang sangat penting, agar penggunaan modal asing serta pinjaman luar negeri dapat dikurangi. Salah satu institusi yang mempunyai peranan penting dalam penghimpun dana masyarakat adalah lembaga perbankan.

Dari ketiga jenis simpanan masyarakat pada bank, yang paling besar porsinya adalah deposito berjangka. Proporsi yang dominan dari deposito berjangka dalam menghimpun dana masyarakat pada bank umum Indonesia terjadi pada tahun 1983, yaitu sebesar $47,3 \%$ dari total dana masyarakat, pada tahun 1996 telah naik menjadi $52 \%$.

Sementara itu, berdasarkan pemilihan sahamnya, bank umum di Indonesia dibagi menjadi 4 (empat), yaitu bank umum pemerintah, bank pemerintah daerah, bank umum swasta nasional, dan bank umum swasta asing. Dari keempat jenis bank umum tersebut, bank umum pemerintah dan bank umum swasta nasional, mempunyai peranan yang dominan dalam penghimpunan deposito berjangka masyarakat.

* Dosen STIMA KOSGORO/Puket I Bidang Akademis 


\subsection{Rumusan Riset}

Berdasarkan latar belakang masalah yang telah diuraikan terdahulu, maka dapat dinyatakan perumusan masalah riset sebagai berikut :

1. Apakah faktor-faktor pendapatan nasional; tingkat bunga deposito pada bank umum pemerintah dan bank umum swasta nasional; tingkat inflasi; total aktiva bank umum pemerintah dan bank umum swasta nasional dan jumlah kantor bank umum pemerintah dan bank umum swasta nasional mempunyai pengaruh yang bermakna terhadap perhimpunan deposita barjangka pada bank umum pemerintah dan bank umum swasta nasional di Indonesia ?.

2. Faktor apakah yang memiliki pengaruh dominan terhadap penghimpunan deposito berjangka pada bank umum pemerintah dan bank umum swasta nasional di Indonesia?.

\subsection{Tujuan Riset}

Berdasarkan latar belakang masalah riset dan perumusan masalah, maka tujuan yang ingin dicapai melalui penelitian ini adalah :

1. Untuk mengetahui pengaruh dari faktor-faktor pendapatan nasional; tingkat bunga deposito pada pada bank umum pemerintah dan bank umum swasta nasional;tingkat inflasi; total aktiva bank umum pemerintah dan bank umum swasta nasional, dan jumlah kantor bank umum pemerintah dan bank umum swasta nasional, terhadap penghimpunan deposita pada bank umum pemerintah dan bank umum swasta nasional di Indonesia.

2. untuk mengetahui faktor yang memiliki pengaruh dominan terhadap penghimpunan deposito berjangka pada bank umum pemerintah dan bank umum swasta nasional.

\section{B. METODE PENELITIAN}

\subsection{Definisi Operasional Variabel}

Untuk menghindari kesimpangsiuran makna dari variabel-variabel yang akan diteliti, maka dalam penelitian ini penulis memberikan batasan sebagai berikut :

1. Pendapatan Nasional (X1) adalah nilai produksi barang dan jasa yang dihasilkan oleh suatu negara dalam satu tahun. Dalam penelitian ini konsep pendapatan nasional yang digunakan adalah Produk Domistik Bruto (PDB) atau Gross Domostic Product (GDP) yang dinyatakan dalam harga konstan tahun 1983.

2. Tingkat Bunga (X2) adalah tingkat keuntungan minimum yang disyaratkan pemodal atau tingkat keuntungan yang diharapkan pemodal dari investasi dalam bentuk simpanan. Tngkat bunga yang dimaksud adalah rata-rata tertimbang tingkat bunga deposito dari seluruh simpanan deposito pada berbagai waktu 
jatuh tempo yang berlaku pada bank umum pemerintah maupun bank umum swasta nasional.

3. Tingkat Inflasi (X3). Adalah kecenderungan dari harga-harga untuk naik secara umum dan terus menerus. Inflasi diukur dari kenaikan Indeks Harga Konsumen per tahun yang dinyatakan dalam persen.

4. Total aktiva bank (X4) adalah jumlah semua aktiva yang dimiliki oleh bank umum pemerintah atau bank umum swasta nasional.

5. Jumlah kantor bank (X5) adalah jumlah semua kantor bank umum pemerintah dan bank umum swasta nasional.

6. Deposito Berjangka (Y) adalah simpanan yang penarikannya hanya dapat dilakukan pada waktu tertentu menurut perjanjian antara penyinpan dengan bank yang bersangkutan. Jangka waktu jatuh tempo deposito berjangka ini adalah 1 bulan, 3 bulan, 6 bulan , 12 bulan dan 24 bulan. Deposito berjangka pada lembaga perbankan di Indonesia terdiri dari deposito berjangka dalam bentuk rupiah dan valuta asing. Deposito dalam penelitian ini adalam deposito dalam bentuk rupiah.

\subsection{Metode Analisis Data}

Untuk mengetahui pengaruh dari masing-masing variabel bebas yang digunakan terhadap variabel tidak bebas, peneliti menggunakan model analisis, dengan persamaan sebagai berikut :

$$
Y=f(X 1, X 2, X 3, X 4, X 5)
$$

Model analisis regresi berganda dibentuk dari persamaan berikut :

$$
\operatorname{Ln} Y=\operatorname{Ln} a_{0}+a_{1} \operatorname{LnX} 1+a_{2} \operatorname{LnX} 2+a_{3} \operatorname{LnX} 3+a_{4} \operatorname{LnX} 4+a_{5} \operatorname{LnX} 5+e
$$

Di mana : $\quad \mathrm{Y}=$ Penghimpunan deposito berjangka pada bank umum pemerintah

$\mathrm{X} 1=$ Pendapatan Nasional

$\mathrm{X} 2$ = Tingkat bunga deposito pada bank umum pemerintah dan bannk umum swasta nasional

$\mathrm{X} 3$ = Tingkat Inflasi

$\mathrm{X} 4=$ Total Aktiva bank umum pemerintah dan bank umum swasta nasional

$\mathrm{X} 5=$ Jumlah kantor bank umum pemerintah dan bank umum swasta nasional.

ai $=$ Parameter yang akan dihitung

$\mathrm{e}=$ Kesalahan pengganggu (error term)

Digunakan bentuk double log/natural log dalam model tersebut di atas mengingat adanya kecedenderungan dari hubungan antar variabel-variabel tersebut di atas mengingat 
adanya kecenderungan dari hubungan antar variabel-variabel tersebut yang bersifat non linier. Selain dari itu ada beberapa keuntungan dari penggunaan model log ganda, antara lain :

1. koefisien regresi parsial/parameter (ai) menunjukkan adanya elastisitas variabel tergantung terhadap variabel bebas.

2. seringkali dapat mengurangi heteroskedastisitas karena tranformasi log dapat memampatkan skala untuk pengukuran variabel.

Untuk menguji hipotesis pertama digunakan uji serentak (uji F) sebagai berikut :

Ho: $a_{1}=a_{2}=a_{2}=a_{3}=a_{4}=a_{5}=0$

$\mathrm{Ha}$ : paling tidak salah satu koefisien regresi $\neq 0$

Dengan menggunakan taraf significkan $5 \%$, apabila nilai $\mathrm{F}$ memiliki probabilitas kurang dari 0,05 , Ho ditolak ( Ha diterima) yang berarti ada pengaruh nyata secara bersama-sama dari X1, X2, X3, X4, X5 terhadap Y.

Sedangkan hipotesis kedua diuji dengan melihat koifisien determinasi parsial dari masing-masing variabel. Variabel yang memiliki pengaruh dominan terhadap variabel tak bebas adalah variabel dengan nilai koefisien determinasi parsial terbesar.

\subsection{Pengujian Hipotesis.}

Untuk menguji kebenaran yang diajukan dalam penelitian ini digunakan analisis regresi berganda. Periode penelitian ini adalah 1984 - 1996 ( 13 tahun ).

Data masing-masing variabel yang dimasukan ke dalam model regresi merupakan data pooling (gabungan time series dan cross section) dari pada bank umum pemerintah dan bank umum swasta nasional. Data tersebut adalah data yang diperoleh dari laporan BI. Dengan mengunakan periode 13 tahun dan teknik polling dilakukan pada dua kelompok sampel (pada bank umum pemerintah dan bank umum swasta nasional), maka didapatkan 26 observasi. Data masing-masing variabel akan dimasukkan pada model regresi berganda, terlihat pada tabel 1.

\section{ANALISIS DATA DAN PEMBAHASAN}

Untuk mengetahui pengaruh secara individual masing-masing variabel bebas terhadap variabel tidak bebas, dengan melihat koefisien regresi parsial (ai). Karena model yang digunakan berbentuk log ganda, maka ai mencerminkan elastisitas variabel tak bebas terhadap variabel bebas., yaitu prosentase perubahan dalam variabel tak bebas untuk prosentase perubahan tertentu dalam variabel bebas. Oleh karena itu ai sering disebut koefisien elastisitas. Dari tabel 2 terlihat bahwa ada dua variabel bebas yang memunyai pengaruh signifikan yaitu pendapatan nasional dan total aktiva bank. Sedangkan elastisitas yang sesaui dengan yang diharapkan, namun tidak mempunyai 
pengaruh yang bermakna terhadap penghimpunan deposito berjangka pada pada bank umum pemerintah dan bank umum swasta nasional.

Pendapatan nasional memiliki pengaruh positip yang bermakna terhadap penghimpunan deposito berjangka pada pada bank umum pemerintah dan bank umum swasta nasional. Hal ini mendukung teori dan penelitian yang dilakukan oleh para peneliti sebelumnya.

Total aktiva pada bank umum pemerintah dan bank umum swasta nasional memiliki pengaruh positip yang bermakna terhadap penghimpunan deposito berjangka pada bank umum pemerintah dan bank umum swasta nasional. Total aktiva yang dimiliki oleh bank, bagi calon penabung merupakan salah satu unsur kredibilitas yang dipertimbangkan sebelum melakukan investasi tabungan.

\section{KESIMPULAN}

Berdasarkan hasil pengujian hipotesis dan pembahasan yang telah dijelaskan pada bab sebelumnya, maka hasil penelitian ini dapat diambil beberapa kesimpulan sebagai berikut :

1. Berdasarkan pengujian hipotesis yang telah dilaksanakan sebelumnya, hipotesis pertama yang mengatakan bahwa terdapat pengaruh yang nyata secara bersamasama dari faktor pendapatan nasional,tingkat bunga pada bank umum pemerintah dan bank umum swasta nasional, tingkat inflasi, total aktiva bank umum pemerintah dan bank umum swasta nasional,dan jumlah kantor bank umum pemerintah dan bank umum swasta nasional di Indonesia diterima. Hal ini terlihat dari nilai $F$ sebesar 147,847 dengan probabilitas kurang daro 0,05.

2. hipotesis kedua yang mengatakanbahwa total aktiva bank umum pemerintah dan bank umum swasta nasional mempunyai pengaruh dominan terhadap penghimpunan deposito berjangka pada bank umum pemerintah dan bank umum swasta nasional diterima. Hal ini dibuktikan dengan koefisien determinasi yang didapat sebesar $64,40 \%$

3. dari lima variabel bebas yang digunakan, hanya dua variabel yang mempunyai pengaruh nyata terhadap penghimpunan deposito pada bank umum pemerintah dan bank umum swasta nasional, yaitu pendapatan nasional dan total aktiva bank. 


\section{REFERENSI}

Abe, shigeyuki, at al., 1977, “ Finance Liberalization an Domistic Saving in Economical Development :An Empirical Test for Six Countries “, Pakistan Development Review, Volume XVI, Islamabad.

Boediono,1998, Ekonomi Moneter, Seri Sinopsis Pengantar Ilmu Ekonomi, no 5 , BPFE, Yogyakarta.

Danoesapoetra, Marjanto, et al.,1990," Peranan dan Prospek Bank Perkreditan Rakyat Dalam Rangka Kebijaksanaan Pakto 1988, Perbimpunan Perbankan, No 25/XOktober/1990, Yayasan Sembada Swakarya , Jakarta.

Fry, Maxwell. J, 1978 " Monetary policy and Domistic Saving in Developing ESCAP Countries", Economic Bulletin for Asia and Pasific, Vol XXIX, No 1 June.

Rose, Peter S, at al., 1993, Financial Institution Understanding and Financial Services, Fourth Edition, IRWIN, Boston

Sinungan, M, 1994, Stategi Manajemen Bank menghadapi Tahun 2000, Penerbit Rineka Cipta, Jakarta.

U Tun Wai, 1972, Financial Intermediaries and National Savings in Developing Countries, Praeger Publisher, New York. 